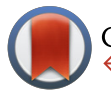

CrossMark \&click for updates

Cite this: Med. Chem. Commun., $2015,6,1767$

Received 6th June 2015

Accepted 4th August 2015

DOI: $10.1039 / \mathrm{c} 5 \mathrm{md} 00242 \mathrm{~g}$

www.rsc.org/medchemcomm

\section{Discovery of pyridyl-based inhibitors of Plasmodium falciparum $\mathrm{N}$-myristoyltransferase $\uparrow$}

\author{
Zhiyong Yu, $\$^{a}$ James A. Brannigan, ${ }^{b}$ Kaveri Rangachari, ${ }^{c}$ William P. Heal, $\S^{a}$ \\ Anthony J. Wilkinson, ${ }^{b}$ Anthony A. Holder, ${ }^{c}$ Robin J. Leatherbarrow $\|^{a}$ \\ and Edward W. Tate*a
}

N-Myristoyltransferase (NMT) represents an attractive drug target in parasitic infections such as malaria due to its genetic essentiality and amenability to inhibition by drug-like small molecules. Scaffold simplification from previously reported inhibitors containing bicyclic cores identified phenyl derivative 3, providing a versatile platform to study the effects of substitution on the scaffold, which yielded pyridyl 19. This molecule exhibited improved enzyme and cellular potency, and reduced lipophilicity compared to inhibitor 3 . Further structure-based inhibitor design led to the discovery of 30, the most potent inhibitor in this series, which showed single-digit nM enzyme affinity and sub- $\mu \mathrm{M}$ anti-plasmodial activity.

\section{Introduction}

Malaria, a parasitic disease in humans primarily caused by Plasmodium falciparum (Pf) and Plasmodium vivax (Pv), was responsible for about 584000 deaths in 2013, mainly of pregnant women and children living in Africa. ${ }^{1}$ Recent vaccine trials have met with moderate success. ${ }^{2,3}$ However, the first signs of resistance to artemisinin, currently the first-line antimalarial treatment, have emerged in Southeast Asia. ${ }^{4-6}$ It is therefore important to develop new antimalarial medications with novel modes of action. ${ }^{7}$

$\mathrm{N}$-Myristoyltransferase (NMT) is an enzyme ubiquitous in eukaryotes, catalysing co- or post-translational transfer of myristate (C14:0 fatty acid) from myristoyl-coenzyme A (myrCoA) to the N-terminal glycine of a subset of eukaryotic

\footnotetext{
${ }^{a}$ Department of Chemistry, Imperial College London, London, SW7 2AZ, UK. E-mail: e.tate@imperial.ac.uk; Tel: +44 (0)2075 943752

${ }^{b}$ York Structural Biology Laboratory, Department of Chemistry, University of York, York, YO10 5DD, UK

${ }^{c}$ The Francis Crick Institute, Mill Hill Laboratory, The Ridgeway, London, NW7 1AA, UK

$\dagger$ Electronic supplementary information (ESI) available: Experimental procedures and characterization of all intermediates, target compounds and X-ray crystallographic data. The coordinates and structure factor files have been deposited in the Protein Data Bank under the accession codes 4UFV (PvNMTNHM-18), 4UFW (PvNMT-NHM-22) and 4UFX (PvNMT-NHM-19). See DOI: 10.1039/c5md00242g

¥ Current address: International Discovery Service Unit, WuXi AppTec, Shanghai, 200131, China.

$\S$ Current address: Department of Chemistry, Kings College London, London SE1 1UL, UK.

9 Current address: Egerton Court, Liverpool John Moores University, Liverpool L1 2UA, UK.
}

proteins. ${ }^{8-12}$ In Plasmodium, numerous essential proteins have been shown to require myristoylation to fulfil their biological functions. ${ }^{13-18}$ The essentiality and druggability of NMT has been demonstrated in blood stage $P$. falciparum, ${ }^{19}$ and in the closely related rodent pathogen $P$. berghei. ${ }^{20} \mathrm{We}$ recently reported the discovery of several novel series of small molecule parasitic NMT inhibitors, ${ }^{19,21-24}$ in addition to peptidomimetic inhibitors. $^{25}$ To date, development of these series has focused on inhibitors containing bicyclic aromatic cores. $^{26-28}$ In two complementary studies, we report the design and development of a simplified single ring scaffold, which provides a more flexible platform to study substitution patterns on the aromatic core and has enabled targeting of both plasmodial and leishmanial NMTs. ${ }^{29}$ Crystal structures of these inhibitors in complex with NMT enabled StructureActivity Relationships (SARs) to be derived; this report describes the discovery of a new highly potent $P$. falciparum NMT (PfNMT) inhibitor that is active against parasites, and with promising selectivity relative to human NMTs and human cell lines. ${ }^{24}$

\section{Results and discussion}

Following the discovery that single-ring scaffolds displayed good affinity against Leishmania donovani NMT, ${ }^{29}$ disubstituted (ortho- and meta-) phenyl rings were selected as analogues of the structures of previously reported inhibitors 1 and $2,,^{27,28}$ and linked through an ester or its bioisosteric oxadiazole to a terminal benzyl substituent (Fig. 1). Among the four different combinations (Table S1, ESI $\dagger$ ), compound 3 was found to display comparable enzyme potency and human selectivity to the bicyclic equivalents (Fig. 1). 
<smiles>O=C(OCc1ccccc1)c1sc2ccccc2c1OC1CCNCC1</smiles>

1

$\mathrm{Ki}(\mu \mathrm{M}): 1.6$ (PfNMT) 2.0 (HsNMT1)<smiles>C=Cc1noc(-c2oc3cccc(OC4CCNCC4)c3c2C)n1</smiles>

2

Ki $(\mu \mathrm{M}): 0.95$ (PfNMT) 23 (HsNMT1)<smiles>C1CCNCC1</smiles><smiles>CCOC(=O)CCc1noc(C)n1</smiles><smiles>C=CC=CC</smiles>

Ki $(\mu \mathrm{M}): 1.4$ (PfNMT)

Fig. 1 Scaffold hopping from previously described inhibitors 1 and 2 containing a bicyclic aromatic core ${ }^{27,28}$ to identify phenyl 3 as a starting compound.

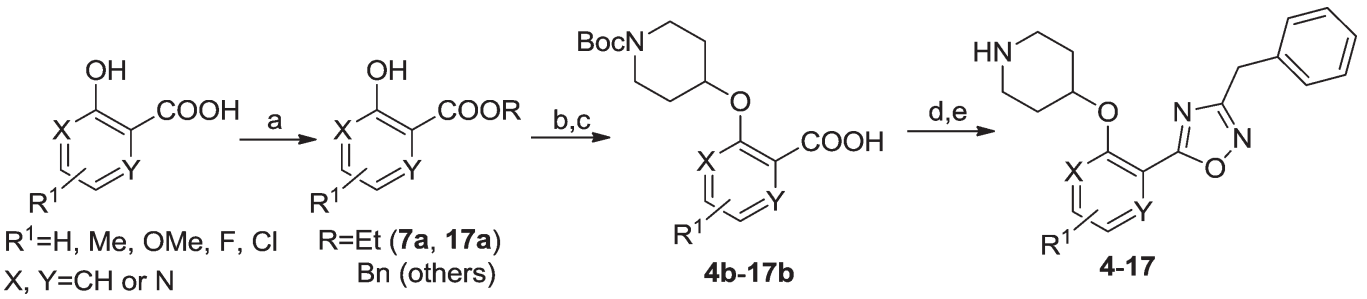

Scheme 1 Reagents: (a) $\mathrm{BnBr}, \mathrm{K}_{2} \mathrm{CO}_{3}, \mathrm{DMF}, \mathrm{rt}, 2 \mathrm{~h}, 86 \%$; as for $\left.7 \mathrm{a}, \mathrm{i}\right) . \mathrm{SOCl}_{2}, 90{ }^{\circ} \mathrm{C}, 1 \mathrm{~h}$; ii) $\mathrm{EtOH}, \mathrm{rt}, 1 \mathrm{~h}, 95 \%$; as for $17 \mathrm{a}, \mathrm{H}_{2} \mathrm{SO} \mathrm{H}_{4}, \mathrm{EtOH} / \mathrm{benzene}, 80$ ${ }^{\circ} \mathrm{C}, 2 \mathrm{~h}, 70 \%$; (b) DIAD, $\mathrm{PPh}_{3}$, $t$-butyl 4-hydroxypiperidine-1-carboxylate, THF, rt, 4 h; (c) $\mathrm{NaOH}, \mathrm{MeOH} / \mathrm{H}_{2} \mathrm{O}, 50{ }^{\circ} \mathrm{C}, 2 \mathrm{~h}$, quantitative over two steps; (d) i). benzylamidoxime, EDCl, HOBt, DIPEA, $\mathrm{CH}_{3} \mathrm{CN}$, rt, 4 h; ii). $0.5 \mathrm{~N} \mathrm{NaOH}, \mathrm{rt}, 0.5 \mathrm{~h}, 90 \%$; (e) 10\% TFA in DCM (v/v), rt, 2 h, quantitative.

Table 1 Enzyme activities of compounds with scaffold substitutions

\begin{tabular}{|c|c|c|c|c|c|c|}
\hline 4 & 3-OMe & $\mathrm{C}$ & $\mathrm{CH}$ & 17 & n.d. & - \\
\hline 5 & 3-Me & C & $\mathrm{CH}$ & 39 & n.d. & - \\
\hline 6 & $3-\mathrm{F}$ & C & $\mathrm{CH}$ & 1.5 & 15 & 10 \\
\hline 7 & $\mathrm{H}$ & $\mathbf{N}$ & $\mathrm{CH}$ & 0.14 & 1.7 & 12 \\
\hline 8 & 4-Me & $\mathrm{CH}$ & $\mathrm{CH}$ & 0.62 & 44 & 70 \\
\hline 9 & 4-OMe & $\mathrm{CH}$ & $\mathrm{CH}$ & 0.18 & 1.2 & 6.8 \\
\hline 14 & $5-\mathrm{F}$ & $\mathrm{CH}$ & $\mathrm{CH}$ & 0.24 & 1.0 & 4.0 \\
\hline 15 & $5-\mathrm{Cl}$ & $\mathrm{CH}$ & $\mathrm{CH}$ & 0.52 & 0.73 & 1.4 \\
\hline 16 & $6-F$ & $\mathrm{CH}$ & $\mathrm{C}$ & 4.8 & n.d. & - \\
\hline 17 & $\mathrm{H}$ & $\mathrm{CH}$ & $\mathbf{N}$ & 29 & n.d. & - \\
\hline
\end{tabular}

${ }^{a}$ Apparent inhibitor dissociation constant $K_{\mathrm{i}}$; half maximal inhibitory concentration $\left(\mathrm{IC}_{50}\right)$ values were determined by a fluorogenic assay ${ }^{30}$ and differences in substrate $K_{\mathrm{m}}$ accounted for using the Cheng-Prusoff equation to give a value for apparent $K_{\mathrm{i}}{ }^{b}$ S.I. $=$ selectivity index, calculated as apparent $K_{\mathrm{i}}(\mathrm{HsNMT1}) /$ apparent $K_{\mathrm{i}}(\mathrm{PfNMT})$.

\section{Variation of the single ring core}

A library of compounds (4-17) with varied substitutions on the single ring scaffold was synthesised (Scheme 1). Initial ester protection of salicylic acid analogues enabled the incorporation of an $\mathrm{N}$-Boc piperidinol side chain into the scaffold via a Mitsunobu reaction, followed by hydrolysis of the ester to form the corresponding carboxylic acid intermediate (4b-17b). The final 1,2,4-oxadiazole compounds were then synthesized using a modification of previously-reported conditions. $^{28}$ 


\begin{tabular}{|c|c|c|c|c|c|c|c|}
\hline Compound & $\mathrm{X}$ & $\mathrm{R}^{1}$ & $\operatorname{clog} P^{a}$ & PfNMT $K_{\mathrm{i}}(\mu \mathrm{M})$ & HsNMT $K_{\mathrm{i}}(\mu \mathrm{M})$ & S.I. & $\operatorname{LipE}^{b}$ \\
\hline 20 & $\mathrm{CH}$ & OMe & 3.20 & 0.071 & 0.43 & 6.1 & 3.95 \\
\hline 21 & $\mathrm{CH}$ & F & 3.54 & 0.071 & 0.54 & 7.6 & 3.61 \\
\hline 22 & $\mathrm{CH}$ & $\mathrm{Cl}$ & 3.96 & 0.03 & 0.36 & 12 & 3.56 \\
\hline
\end{tabular}

(a)

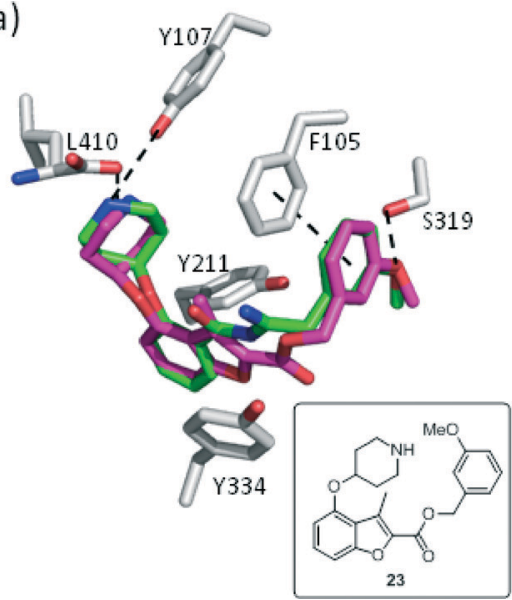

(b)

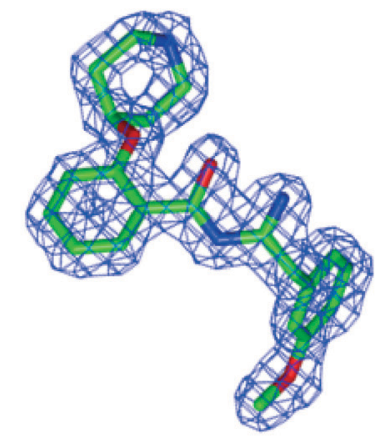

(c)

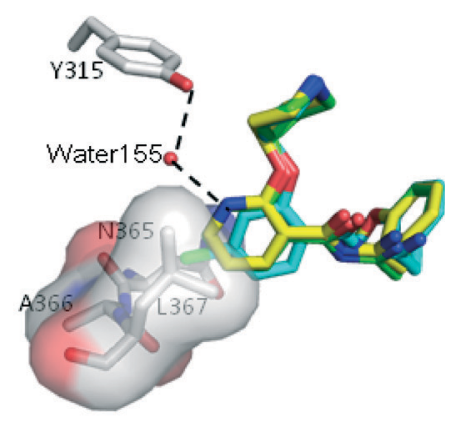

Fig. 2 Structural overlays help to rationalize the SAR for 18, 19 and 23: (a) 18 (PDB code: 4UFV, $1.80 \AA$, green) binds to the enzyme (grey) in a similar way to 23 (PDB code: 4B14, magenta); (b) unexpected ring-open oxadiazole observed in the electron density map of 18 (C green); (c) 19 (PDB code: 4UFX, $1.51 \AA$ A yellow) picks up an additional water-mediated hydrogen bond and shares identical binding positions to 18 (green); while insertion of chlorine at C-4 allows the hydrophobic interaction with the pocket comprising of N365, A366 and L367 (22, PDB code: 4 UFW, 1.54 A, cyan). Atoms are colored: $\mathrm{N}$ blue, $\mathrm{O}$ (non-water) red, $\mathrm{O}$ (water) red sphere.

The biological activities of these compounds are detailed in Table 1. Substitution at C-3 was disfavored for inhibition of PfNMT (4 and $5 v s$. 3, Table 1), with only fluorine (6) tolerated at this position by the enzyme. However, the 3-pyridyl analogue of 3 exhibited both reduced lipophilicity and a 10fold improvement in enzyme affinity ( 7 vs. 3). Within the phenyl series, substitution at the C-4 position generally enhanced enzyme inhibition, with methyl (8vs. 3) somewhat less effective than halogen $(10,11$ vs. 3) or methoxy (9), with minor variations in selectivity over the human enzyme. Electron-donating substituents at C-5 $(12,13)$ were disfavored and electron-withdrawing substituents favored $(\mathbf{1 4}, \mathbf{1 5})$ with respect to inhibition of PfNMT, but were accompanied by a drop in selectivity over human NMT. Changes at the C-6 position $(16,17)$ were poorly tolerated.

\section{3-OMe phenyl as the terminal aromatic moiety}

Based on enzyme potency and S.I. values, cores from compounds 7, 9, 10 and 11 were selected for further development, and a terminal 3-OMe phenyl moiety was selected for incorporation via the oxadiazole linker, based on our previous work. ${ }^{28}$ The corresponding compounds 19-22 along with the unsubstituted phenyl analogue 18 were prepared and it was found that addition of a 3-methoxy group generally enhances PfNMT inhibition activity, although at the expense of some human selectivity (19-22 in Table 2 vs. 7, 9, 10 and 11 in Table 1). Compound 19 was selected as the frontrunner inhibitor at this stage given its balance of good potency and selectivity; furthermore, its higher LipE value is attractive for further development. ${ }^{31,32}$

\section{Structural studies}

P. vivax (Pv) NMT shares $81 \%$ sequence identity with PfNMT, and has been successfully used to guide the discovery of potent PfNMT inhibitors. ${ }^{26-28}$ In order to interpret the effect of substitution on the scaffold, inhibitors derived from phenyl (18), 4-chloro phenyl (22) and 3-pyridyl (19) were selected for crystallographic studies and co-crystal structures with a 
(a)
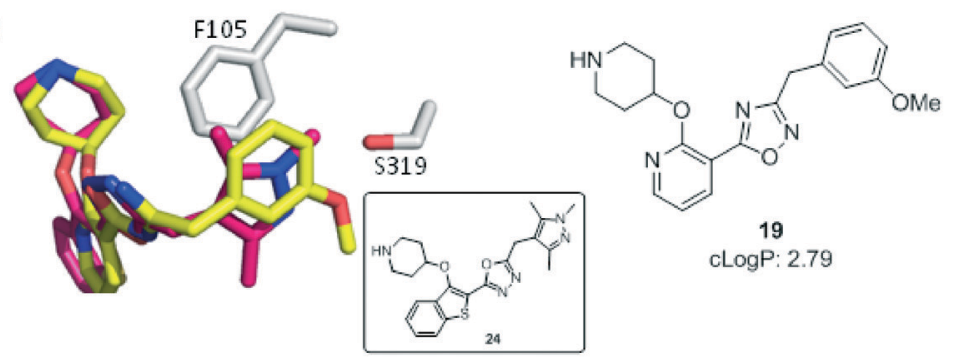

(b)

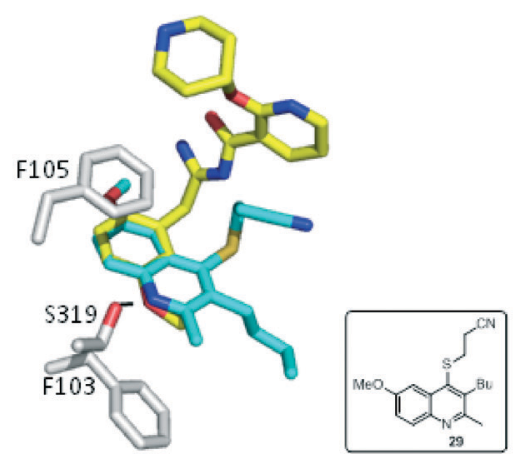

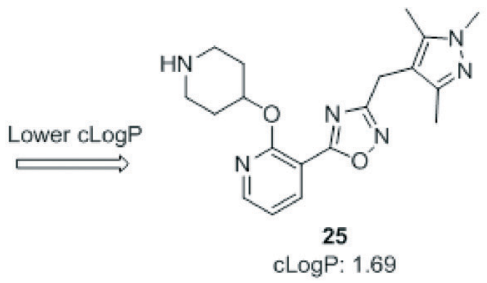
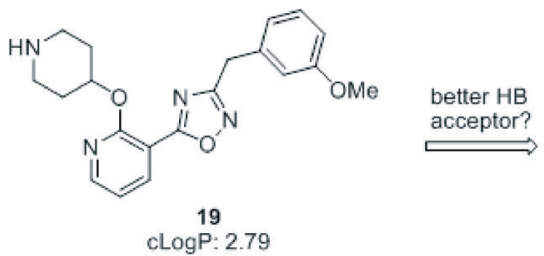

Fig. 3 Structure-guided design: (a) overlay of 3-OMe phenyl in 19 (PDB code: 4UFX, yellow) with the pyrazole in 24 (PDB code: 4CAF, magenta). Both motifs bind at the S319 pocket; (b) 3-OMe phenyl in 19 superimposes well with the quinoline in 29 (PDB code: 4A95, cyan). Atoms are colored: C (enzyme) grey, $\mathrm{N}$ blue, $\mathrm{O}$ red, $\mathrm{S}$ orange.

non-hydrolysable myr-CoA analogue (NHM) ${ }^{30}$ and PvNMT were obtained. As expected, inhibitor 18 shows a very similar binding mode to a previously reported inhibitor 23 (Fig. 2a). ${ }^{28}$ Surprisingly, electron density maps suggest the formation of a ring-open analogue of the oxadiazole for these three test compounds within the crystal (the corresponding analogue for 18 is shown in Fig. 2b), although the desired closed ring was confirmed for the pure isolated inhibitors by both NMR and high resolution mass spectrometry $\left([\mathrm{M}+\mathrm{H}]^{+}\right.$ $=366.1801$, which matches well with its closed ring form), and they were found to be stable under conditions covering a $\mathrm{pH}$ range between 1 and 10 (data not shown). This interesting phenomenon was also observed in the related series<smiles>CC(=O)CC(C)=O</smiles><smiles></smiles><smiles>[R10]N1CCC(Oc2ncccc2-c2nc(Cc3c(C)nn(C)c3C)no2)CC1</smiles>

Scheme 2 Reagents: (a) bromoacetonitrile, NaH, THF, rt, 4 h, 40\%; (b) i) mono-methylhydrazine, $\mathrm{MeOH}$, reflux, $4 \mathrm{~h}$; ii) hydroxylamine, $\mathrm{MeOH}$, reflux, $6 \mathrm{~h}, 95 \%$; (c) i). 7b, EDCl, $\mathrm{HOBt}$, DIPEA, $\mathrm{CH}_{3} \mathrm{CN}, \mathrm{rt}, 4 \mathrm{~h}$; ii). $0.5 \mathrm{~N}$ $\mathrm{NaOH}, \mathrm{rt}, 0.5$ h, 90\%; (d) 10\% TFA in DCM (v/v), rt, 2 h, quantitative; (e) aldehyde or ketone, $\mathrm{NaBH}(\mathrm{OAc})_{3}, \mathrm{MeOH}, \mathrm{rt}, 12 \mathrm{~h}, 80 \%$. crystallised in $\mathrm{LmNMT}^{29}$ and further work will be required to understand its origin; however, it did not impact on our subsequent development of the oxadiazole series. The basic piperidine moiety establishes an ion-pairing interaction with the C-terminal carboxylate (L410) and a cation-dipole interaction with the Y107 hydroxyl, whilst the 3-OMe phenyl forms hydrogen bonding (HB) and $\pi-\pi$ interactions with the S319 hydroxyl and F105, respectively (Fig. 2a). The 1,2,4-oxadiazole moiety is sandwiched between Y334 and Y211, forming hydrophobic interactions with these two residues. The observed substitution effects of the core can be clarified by examination of the bound structures (Fig. 2c). Pyridyl 19 is superimposed with phenyl 18, where the pyridyl nitrogen participates in an additional water-mediated HB with the Y315 hydroxyl, providing an explanation for the observed 8-fold enhancement in inhibition (19 vs. 18, Table 2). 4-Cl in 22 inserts into a hydrophobic pocket formed by N365, A366 and L367; we hypothesise that such hydrophobic interaction provides the observed activity improvement ( $22 v s$. 18, Table 2).

\section{Structure-guided development}

We next considered replacements for the 3-OMe phenyl moiety. A structural overlay with $\mathbf{2 4}$, a previously reported $\mathbf{P v} / \mathbf{P f}$ NMT inhibitor, ${ }^{26}$ suggests that the 1,3,5-trimethylpyrazole shares a similar binding mode to methoxyphenyl (Fig. 3a). Pyrazole 25 was thus prepared (Scheme 2). Although it showed higher LipE than 19, there was no potency boost in either enzyme or cellular level while its $N$-alkyl piperidine derivatives (26-28) suffered from modest to significant activity drop (Table 3). Another PvNMT inhibitor (29) identified from an earlier screening campaign,${ }^{23}$ was found to overlay 
Table 3 Biological activities of inhibitors guided by overlaying crystal structures

\begin{tabular}{|c|c|c|c|c|c|c|c|c|c|}
\hline Compd no. & $\mathrm{R}^{2}$ & $\mathbf{R}^{3}$ & $\operatorname{clog} P^{a}$ & $\operatorname{PfNMT} K_{\mathrm{i}}(\mu \mathrm{M})$ & $\operatorname{LipE}^{b}$ & HsNMT $K_{\mathrm{i}}(\mu \mathrm{M})$ & S.I. ${ }^{c}$ & $\mathrm{EC}_{50}{ }^{d}(\mu \mathrm{M})$ & $\mathrm{LD}_{50}{ }^{e}(\mu \mathrm{M})$ \\
\hline 25 & & $\mathrm{H}$ & 1.69 & 0.028 & 5.86 & 0.20 & 7 & 3.7 & $>100$ \\
\hline 26 & & $\mathrm{Me}$ & 2.09 & 0.57 & 4.15 & 0.51 & 0.9 & $>30$ & n.d. ${ }^{f}$ \\
\hline 28 & & $i$-Pr & 2.85 & 0.090 & 4.20 & 0.18 & 2 & 3.2 & $>100$ \\
\hline 30 & & $\mathrm{H}$ & 3.14 & 0.0017 & 5.63 & 0.024 & 14 & 0.21 & 65 \\
\hline
\end{tabular}

${ }^{a} \operatorname{cog} P$ values calculated using ChemAxon software. ${ }^{b} \mathrm{LipE}=\mathrm{p} K_{\mathrm{i}}(\mathrm{PfNMT})-\operatorname{clog} P .{ }^{c}$ S.I., calculated as $K_{\mathrm{i}}(\mathrm{HsNMT1}) / K_{\mathrm{i}}(\mathrm{PfNMT}) .{ }^{d} P$. falciparum, 3D7 line was used. ${ }^{e}$ HepG2 cell line was used. ${ }^{f}$ n.d. $=$ not determined.<smiles>N#Cc1cccc2ncccc12</smiles>

Scheme 3 Reagents: (a) $\mathrm{NaBH}_{4}, \mathrm{MeOH}, \mathrm{rt}, 8 \mathrm{~h}$; (b) $\mathrm{MsCl}, \mathrm{DCM}, 0{ }^{\circ} \mathrm{C}, 3 \mathrm{~h}$; (c) $\mathrm{NaCN}, \mathrm{DMSO}, 60{ }^{\circ} \mathrm{C}, 1 \mathrm{~h}, 22 \%$ over three steps; (d) hydroxylamine, $\mathrm{MeOH}$, reflux, 6 h, 97\%; (e) i). 7b, EDCl, HOBt, DIPEA, $\mathrm{CH}_{3} \mathrm{CN}$, rt, 4 h; ii). $0.5 \mathrm{~N} \mathrm{NaOH}, \mathrm{rt}, 0.5$ h, 90\%; (f) 10\% TFA in DCM (v/v), rt, 2 h, quantitative.

well with the 3-OMe phenyl moiety in 19 (Fig. 3b). Encouragingly, the combination of quinoline and pyridyl scaffold yielded inhibitor 30 (Scheme 3), which posted a 14-fold increase in both enzyme and cellular potency over 19, with only two heavy atoms added and no compromise in enzyme selectivity over human NMT or acute toxicity against mammalian cells over 48 hours (30 vs. 19, Table 3). We hypothesise that the improved $\mathrm{HB}$ acceptor strength of the quinoline ${ }^{33}$ contributes to the observed increase in activity.

\section{Conclusion}

Scaffold reduction from our earlier PfNMT inhibitors containing bicyclic cores to phenyl-based inhibitors provided a flexible platform to study the effect of scaffold and substituent variations, allowing the discovery of pyridyl as an attractive core, the superiority of which was later explained by structural studies. Further development was achieved through crystallography-guided hybridization of this scaffold with two existing NMT inhibitors, leading to the discovery of 30, a promising PfNMT inhibitor with excellent enzyme affinity and good cellular efficacy. Further lead optimization is underway in an attempt to further improve the cellular potency of this series, with the aim of progressing towards in vivo studies.

\section{Acknowledgements}

This work was supported by the Wellcome Trust (grant no. 087792), the Medical Research Council (grant no. 0900278 
and U117532067) and the Francis Crick Institute which receives its core funding from Cancer Research UK, the UK Medical Research Council and the Wellcome Trust. The authors are grateful to Andrew Bell, Mark Rackham and Jennie Hutton for valuable discussions. We thank Munira Grainger for providing the parasites and red blood cells used in the in vitro parasite assay, Shirley Roberts for crystal handling and Johan Turkenburg for X-ray data processing. We also acknowledge the Diamond Light Source for synchrotron facilities.

\section{References}

1 World Malaria Report 2014, 2014, World Health Organization, Geneva.

2 The RTS,S Clinical Trials Partnership, N. Engl. J. Med., 2012, 367, 2284.

3 A. Opar, Nat. Rev. Drug Discovery, 2011, 10, 887.

4 J. Straimer, N. F. Gnadig, B. Witkowski, C. Amaratunga, V. Duru, A. P. Ramadani, M. Dacheux, N. Khim, L. Zhang, S. Lam, P. D. Gregory, F. D. Urnov, O. Mercereau-Puijalon, F. Benoit-Vical, R. M. Fairhurst, D. Menard and D. A. Fidock, Science, 2015, 347, 428.

5 A. P. Phyo, S. Nkhoma, K. Stepniewska, E. A. Ashley, S. Nair, R. McGready, C. ler Moo, S. Al-Saai, A. M. Dondorp, K. M. Lwin, P. Singhasivanon, N. P. J. Day, N. J. White, T. J. C. Anderson and F. Nosten, Lancet, 2012, 379, 1960.

6 A. M. Dondorp, F. Nosten, P. Yi and D. Das, N. Engl. J. Med., 2009, 361, 455.

7 J. N. Burrows, E. Burlot, B. Campo, S. Cherbuin, S. Jeanneret, D. Leroy, T. Spangenberg, D. Waterson, T. N. Wells and P. Willis, Parasitology, 2014, 141(Special Issue 01), 128.

8 E. W. Tate, K. A. Kalesh, T. Lanyon-Hogg, E. M. Storck and E. Thinon, Curr. Opin. Chem. Biol., 2015, 24, 48.

9 E. Thinon, R. A. Serwa, M. Broncel, J. A. Brannigan, U. Brassat, M. H. Wright, W. P. Heal, A. J. Wilkinson, D. J. Mann and E. W. Tate, Nat. Commun., 2014, 5, 4919.

10 E. W. Tate, A. S. Bell, M. D. Rackham and M. H. Wright, Parasitology, 2014, 141, 37-49.

11 M. Wright, W. Heal, D. Mann and E. Tate, J. Chem. Biol., 2010, 3, 19.

12 D. R. Johnson, R. S. Bhatnagar, L. J. Knoll and J. I. Gordon, Annu. Rev. Biochem., 1994, 63, 869.

13 D. Guttery, S. Poulin, B. Ramaprasad, A. Wall, R. J. Ferguson, D. J. P. Brady, D. Patzewitz, E. M. Whipple, S. Straschil, M. H. Wright, A. Mohamed, M. A. H. Radhakrishnan, A. S. T. Arold, E. W. Tate, A. A. Holder, B. Wickstead, A. Pain and R. Tewari, Cell Host Microbe, 2014, 16, 128.

14 B. Poulin, E. M. Patzewitz, D. Brady, O. Silvie, M. H. Wright, D. J. P. Ferguson, R. J. Wall, S. Whipple, D. S. Guttery, E. W. Tate, B. Wickstead, A. A. Holder and R. Tewari, Biol. Open, 2013, 2, 1160.

15 W. Leber, A. Skippen, Q. L. Fivelman, P. W. Bowyer, S. Cockcroft and D. A. Baker, Int. J. Parasitol., 2009, 39, 645.
16 J. L. Green, R. R. Rees-Channer, S. A. Howell, S. R. Martin, E. Knuepfer, H. M. Taylor, M. Grainger and A. A. Holder, J. Biol. Chem., 2008, 283, 30980.

17 R. R. Rees-Channer, S. R. Martin, J. L. Green, P. W. Bowyer, M. Grainger, J. E. Molloy and A. A. Holder, Mol. Biochem. Parasitol., 2006, 149, 113.

18 W. H. L. Stafford, R. W. Stockley, S. B. Ludbrook and A. A. Holder, Eur. J. Biochem., 1996, 242, 104.

19 M. H. Wright, B. Clough, M. D. Rackham, K. Rangachari, J. A. Brannigan, M. Grainger, D. K. Moss, A. R. Bottrill, W. P. Heal, M. Broncel, R. A. Serwa, D. Brady, D. J. Mann, R. J. Leatherbarrow, R. Tewari, A. J. Wilkinson, A. A. Holder and E. W. Tate, Nat. Chem., 2014, 6, 112.

20 P. Pino, S. Sebastian, E. A. Kim, E. Bush, M. Brochet, K. Volkmann, E. Kozlowski, M. Llinas, O. Billker and D. Soldati-Favre, Cell Host Microbe, 2012, 12, 824.

21 J. A. Hutton, V. Goncalves, J. A. Brannigan, D. Paape, M. H. Wright, T. M. Waugh, S. M. Roberts, A. S. Bell, A. J. Wilkinson, D. F. Smith, R. J. Leatherbarrow and E. W. Tate, J. Med. Chem., 2014, 57, 8664.

22 J. A. Brannigan, S. M. Roberts, A. S. Bell, J. A. Hutton, M. R. Hodgkinson, E. W. Tate, R. J. Leatherbarrow, D. F. Smith and A. J. Wilkinson, IUCrJ, 2014, 1, 250.

23 V. Goncalves, J. A. Brannigan, D. Whalley, K. H. Ansell, B. Saxty, A. A. Holder, A. J. Wilkinson, E. W. Tate and R. J. Leatherbarrow, J. Med. Chem., 2012, 55, 3578.

24 A. S. Bell, J. E. Mills, G. P. Williams, J. A. Brannigan, A. J. Wilkinson, T. Parkinson, R. J. Leatherbarrow, E. W. Tate, A. A. Holder and D. F. Smith, PLoS Neglected Trop. Dis., 2012, 6, e1625.

25 T. O. Olaleye, J. A. Brannigan, S. M. Roberts, R. J. Leatherbarrow, A. J. Wilkinson and E. W. Tate, Org. Biomol. Chem., 2014, 12, 8132.

26 M. D. Rackham, J. A. Brannigan, K. Rangachari, S. Meister, A. J. Wilkinson, A. A. Holder, R. J. Leatherbarrow and E. W. Tate, J. Med. Chem., 2014, 57, 2773.

27 M. D. Rackham, J. A. Brannigan, D. K. Moss, Z. Yu, A. J. Wilkinson, A. A. Holder, E. W. Tate and R. J. Leatherbarrow, J. Med. Chem., 2013, 56, 371.

28 Z. Yu, J. A. Brannigan, D. K. Moss, A. M. Brzozowski, A. J. Wilkinson, A. A. Holder, E. W. Tate and R. J. Leatherbarrow, J. Med. Chem., 2012, 55, 8879.

29 M. D. Rackham, Z. Yu, J. A. Brannigan, W. P. Heal, D. Pappe, K. V. Barker, A. J. Wilkinson, D. F. Smith, R. J. Leatherbarrow and E. W. Tate, Med. Chem. Commun., DOI: 10.1039/c5md00241.

30 V. Goncalves, J. A. Brannigan, E. Thinon, T. O. Olaleye, R. Serwa, S. Lanzarone, A. J. Wilkinson, E. W. Tate and R. J. Leatherbarrow, Anal. Biochem., 2012, 421, 342.

31 A. L. Hopkins, G. M. Keseru, P. D. Leeson, D. C. Rees and C. H. Reynolds, Nat. Rev. Drug Discovery, 2014, 13, 105.

32 A. Tarcsay, K. Nyiri and G. M. Keseru, J. Med. Chem., 2012, 55, 1252.

33 H. J. Böhm, S. Brode, U. Hesse and G. Klebe, Chem. - Eur. J., 1996, 2, 1509. 